\title{
REQUIREMENTS FOR VITAMIN C IN MAN
}

\author{
By MARTIN HEINEMANN 1 \\ (From the Department of Internal Medicine, Yale University School of Medicine, New Haven)
}

(Received for publication June 2, 1938)

Tests for requirements for vitamin $\mathrm{C}$ give varying results according to the criteria which are established; for example, there are the widely different requirements $(i)$ for complete saturation and (ii) for protection against scurvy. In guinea pigs, doses of ascorbic acid which assure normal growth curves and freedom from scurvy are not sufficient to protect against the early pathological changes caused by deficiency of this vitamin $(1,2,3,4)$. It has been shown also that these animals are protected against scurvy by very small doses of vitamin $C$ although their tissues contain scarcely detectable amounts of this vitamin $(5,6)$. In man, also, the daily dose of ascorbic acid adequate to prevent scurvy is far less than that required to maintain saturation of the body. In this paper, the latter amounts, viz., the doses used by saturated subjects under normal and pathological conditions, have been investigated.

If a previously saturated subject is resaturated after having omitted all vitamin $\mathrm{C}$ for a certain length of time, the dose of ascorbic acid required to produce saturation corresponds to the quantity used from the body stores during the vitamin Cfree period. Consequently, this amount when divided by the number of days the experiment lasted, can be considered as the daily expenditure $(7,8)$. Saturation, as referred to in this paper, is defined as the condition when considerable portions of a moderate test dose of ascorbic acid appear in the urine. Under these circumstances the tissues contain maximal quantities of ascorbic acid and, in man, the concentration in whole blood is 14 to $15 \mathrm{mgm}$. per liter. Unless maximal amounts have been stored, the body retains administered ascorbic acid avidly; beyond this point of saturation, however, any excess of ascorbic acid is rapidly wasted into the urine, a fact on which the saturation test is based $(9,10,11)$. As stated before, the estimation of the daily requirements of vitamin $C$ depends necessarily on the criteria applied.

\footnotetext{
1 Honorary Fellow.
}

\section{HEALTHY SUBJECTS}

At one extreme, about $0.4 \mathrm{mgm}$. per $\mathrm{kgm}$. daily is sufficient to protect against abnormal capillary permeability resulting from deficiency of vitamin C $(12,13,14)$. At the other extreme, more than $0.8 \mathrm{mgm}$. per $\mathrm{kgm}$. is metabolized daily by a subject saturated with ascorbic acid $(7,8)$. All variations are possible between these extremes. By his method, van Eekelen has demonstrated that the further removed from saturation the subject is, the smaller is the amount metabolized daily. The amounts required to produce saturation have been calculated as $0.4 \mathrm{mgm}$. per $\mathrm{kgm}$. after 94 days, as about $0.55 \mathrm{mgm}$. per $\mathrm{kgm}$. after 40 days, and as about $0.8 \mathrm{mgm}$. per $\mathrm{kgm}$. after 27 days of vitamin $C$ deprivation $(7,8)$. Probably even more than $0.8 \mathrm{mgm}$. per $\mathrm{kgm}$. would be metabolized at complete saturation levels. That for the maintenance of a lower level of vitamin $C$ reserves less is required is shown in another way by the following experiment. A subject $(78 \mathrm{kgm}$.) partly depleted as the result of a diet devoid of vitamin $\mathrm{C}$, was supplied with about $0.5 \mathrm{mgm}$. per $\mathrm{kgm}$. ( $40 \mathrm{mgm}$.) daily per os for 16 days. The concentration of ascorbic acid in whole blood had not changed during this period (5.4 mgm. per liter on February 28, $5.5 \mathrm{mgm}$. per liter on March 16). In whole blood (56), an ascorbic acid concentration of 14 to $15 \mathrm{mgm}$. per liter indicates saturation; about or less than 2 mgm. per liter have been observed in scurvy. This small intake of about $0.5 \mathrm{mgm}$. per $\mathrm{kgm}$. prevented further decline in the blood level. That it fell far short of causing saturation is demonstrated by the failure of a test dose of $750 \mathrm{mgm}$. of ascorbic acid, taken as a single dose per os, to cause any increase in the urinary excretion. While from this observation $0.5 \mathrm{mgm}$. per $\mathrm{kgm}$. can not be considered to cover maximal demands and to produce saturation in a depleted organism, it appears that this dose just maintains a blood level of about 5 to $6 \mathrm{mgm}$. per liter, at which level no clinical manifestations of scurvy have as yet been observed. 
There is experimental evidence that $0.4 \mathrm{mgm}$. per $\mathrm{kgm}$. daily represents the minimal requirement only and does not meet maximal demands. A subject was saturated and thereafter supplied daily with $0.33 \mathrm{mgm}$. per $\mathrm{kgm}$. for 32 days (15), and on another occasion with $0.5 \mathrm{mgm}$. per $\mathrm{kgm}$. for the longer period of 53 days (16). In both instances a total of $16 \mathrm{mgm}$. per $\mathrm{kgm}$. was necessary for resaturation. The blood content had fallen from the saturation level of 14 to $15 \mathrm{mgm}$. per liter to $7.2 \mathrm{mgm}$. and $6.4 \mathrm{mgm}$. per liter respectively. Under both these experimental conditions, requirements calculated according to the method described in principle above also amount to 0.82 mgm. per kgm. (17).

These maximal requirements of $0.8 \mathrm{mgm}$. per $\mathrm{kgm}$. daily may represent somewhat more than the optimum because there is no clinical evidence that a smaller supply, e.g., $0.6 \mathrm{mgm}$. per $\mathrm{kgm}$. has any deleterious effect. Furthermore, it has already been shown that the amount of ascorbic acid used by the body decreases to some extent when the body stores diminish.

Table I summarizes the results of determining maximal requirements in normal adults $(8,17$,

TABLE I

Vitamin $C$ requirements of normal subjects

\begin{tabular}{|c|c|c|c|c|}
\hline \multirow[t]{2}{*}{ Subject } & \multirow{2}{*}{$\begin{array}{l}\text { Age } \\
\text { years }\end{array}$} & \multirow{2}{*}{$\begin{array}{c}\text { Weight } \\
\text { kilos }\end{array}$} & \multicolumn{2}{|c|}{$\begin{array}{l}\text { Daily requirements of } \\
\text { ascorbic acid }\end{array}$} \\
\hline & & & $m g m$. & $\underset{\mathrm{kgm} .}{\operatorname{mgm} . \text { per }}$ \\
\hline 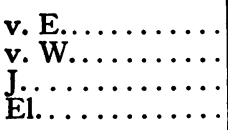 & $\begin{array}{l}30 \\
38 \\
18 \\
25\end{array}$ & $\begin{array}{l}90 \\
72 \\
53 \\
68\end{array}$ & $\begin{array}{l}63 \\
56 \\
44 \\
53\end{array}$ & $\begin{array}{l}0.70 \\
0.77 \\
0.83 \\
0.78\end{array}$ \\
\hline H... & 37 & 75 & $\begin{array}{l}63 \\
63\end{array}$ & $\begin{array}{l}0.84 \\
0.84\end{array}$ \\
\hline
\end{tabular}

$18,19)$, including one subject $(\mathrm{J})$ with scurvy (19). Results agreeing closely to 0.83 to 0.84 mgm. per $\mathrm{kgm}$. were obtained by calculating the weights for the experimental subjects from a weight-height-age table (20). As can be seen, maximal requirements in man are correlated with weight; this has been observed also for minimal requirements in man (14) and for guinea pigs (4). It has been suggested that requirements are comparatively larger in children than in adults $(21,22,23)$; they are not larger in young guinea pigs than in old ones (4). O'Hara and Hauck (24) investigated the storage of vitamin $C$ in 4 normal adults; their data (kindly supplemented by a personal communication) also indicates that the optimum requirement is considerably greater than the amount of vitamin $C$ necessary to prevent scurvy. Thirty mgm. of ascorbic acid have been postulated as the daily minimum, $50 \mathrm{mgm}$. as the daily optimum for the German population (25). There is some evidence that requirement for vitamin $\mathrm{C}$ varies with the total metabolism $(26,27,28,29)$, but it is apparently immaterial whether the calories are supplied by protein or carbohydrate (18).

From the foregoing, it follows that at least 0.8 mgm. per kgm. of ascorbic acid is used daily by a saturated subject. Smaller doses, e.g., $0.5 \mathrm{mgm}$. per $\mathrm{kgm}$. or even less, are sufficient to protect against scurvy. But, even if it is true that smaller doses may assure good health under optimal conditions, it would seem useful to supply the maximum requirements as a factor of safety against altered circumstances which may increase requirements.

\section{DISEASED SUBJECTS}

An abnormally high supply seems to be needed in many diseases $(30,31,32,33,34,35)$, but this does not appear to be specific for any one disease. So far, the knowledge concerning ascorbic acid requirement in disease is very incomplete; the methods applied to the problem have not always been adequate (36). Data obtained by the method of van Eekelen on a small group of patients are presented in Table II. From the table it follows that requirements are unusually high in cases of tuberculosis $(37,38)$. This agrees with observations by Heise and Martin (39) who, by a different method, found that 55 to $138 \mathrm{mgm}$. of ascorbic acid daily were required by a group of 44 tuberculous patients. These authors and others $(40,41,42)$ also observed that the stores of vitamin $C$ in the tuberculous organism are very insufficient. Fever has been considered as an important factor causing exhaustion of body stores $(33,35,43)$; this may be referable to the increased total metabolism during fever. On the other hand, it appears from observations of $\mathrm{Pa}$ tients $N$ and v.D. that requirements can be increased in spite of normal body temperature. The 
TABLE II

Vitamin $C$ requirements of diseased subjects

\begin{tabular}{|c|c|c|c|c|}
\hline \multirow[t]{2}{*}{ Subject } & \multirow[t]{2}{*}{ Diagnosis } & \multirow{2}{*}{$\begin{array}{l}\text { Weight } \\
\text { kilos }\end{array}$} & \multicolumn{2}{|c|}{$\begin{array}{l}\text { Daily re- } \\
\text { quirements } \\
\text { of ascorbic } \\
\text { acid }\end{array}$} \\
\hline & & & $m g m$. & mem. \\
\hline & $\begin{array}{l}\text { Active pulmonary tuberculosis; } \\
\text { high temperature }\end{array}$ & 59 & 82 & 1.4 \\
\hline L.. & $\begin{array}{l}\text { Active pulmonary tuberculosis; } \\
\text { high temperature }\end{array}$ & 55 & 139 & 2.5 \\
\hline V. & $\begin{array}{l}\text { Active pulmonary tuberculosis; } \\
\text { high temperature }\end{array}$ & 50 & 110 & 2.2 \\
\hline & $\begin{array}{l}\text { Active pulmonary tuberculosis; } \\
\text { high temperature }\end{array}$ & 44 & 93 & 2.1 \\
\hline & $\begin{array}{l}\text { Tuberculosis (spondylitis); nor- } \\
\text { mal temperature }\end{array}$ & 72 & 86 & 1.2 \\
\hline & $\begin{array}{l}\text { Healed tuberculosis; normal } \\
\text { temperature (pleurisy } 7 \\
\text { months ago) }\end{array}$ & 55 & 45 & 0.8 \\
\hline v. & $\begin{array}{l}\text { Empyema following pneu- } \\
\text { monia; normal temperature }\end{array}$ & 44 & 90 & 2.0 \\
\hline v. 1 & $\begin{array}{l}\text { Empyema following pneu- } \\
\text { monia; low grade fever }\end{array}$ & 45 & 57 & 1.3 \\
\hline & $\begin{array}{l}\text { Osteosclerotic (?) anemia. } \\
\text { Normal gastric acidity. } \\
\text { B. M. R. }-5 \text {; low grade fever }\end{array}$ & 76 & 121 & 1.6 \\
\hline $\begin{array}{l}\text { St. } \\
\text { Bl: } \\
\text { V. } \\
\text { M. } \\
\text { R. }\end{array}$ & $\begin{array}{l}\text { Peptic ulcer } \\
\text { Peptic ulcer } \\
\text { Peptic ulcer } \\
\text { Peptic ulcer } \\
\text { Peptic ulcer }\end{array}$ & $\begin{array}{c}65 \\
63 \\
50 \\
69 \\
?\end{array}$ & $\begin{array}{l}83 \\
75 \\
65 \\
83 \\
85\end{array}$ & $\begin{array}{l}1.3 \\
1.2 \\
1.3 \\
1.2 \\
?\end{array}$ \\
\hline
\end{tabular}

* While, as a rule, ascorbic acid was given by mouth, these patients received it subcutaneously in order to exclude the possibility that faulty absorption might only simulate increased requirements.

observation of normal requirements in a case (E.) of healed tuberculous pleurisy without any symptoms of activity agrees with results of saturation tests from which Abbasy et al. (34) concluded that body stores are normal in cases of quiescent surgical tuberculosis, while in active cases they are depleted. Increased requirements have been demonstrated also in tuberculous guinea pigs; kept on a diet devoid of vitamin $\mathrm{C}$, they develop scurvy earlier than a healthy control group (44, 45). A report from South Africa similarly shows that the incidence of scurvy among the natives rises with the morbidity from tuberculosis (46, 47). These observations indicate that tuberculosis predisposes to scurvy by increasing the requirements for vitamin $C$. Amounts that will meet normal demands become inadequate.

It has been suggested before that the amounts required to maintain complete saturation may be even higher than those estimated by the method of van Eekelen employed for the present study.
This suggestion appeared to be substantiated by the following observation: when a patient $(\mathrm{J})$ was placed on his calculated daily amount for 2 weeks, the blood content decreased from 13.4 mgm. per $1000 \mathrm{cc}$. of whole blood to 8.7, at which level at least $600 \mathrm{mgm}$. of ascorbic acid would have been needed for resaturation. Abnormally increased requirements are not specific for tuberculosis as follows from determinations in other diseases (Patients v.D., v.E., and Th.).

Requirements have been found to be increased to some extent in patients with peptic ulcer, in whom similar experimental data were obtained by either oral or subcutaneous administration of the vitamin (Table II). Saturation tests have revealed that deficiency of vitamin $C$ is rather common in this group of patients $(32,48,49,50,51)$; but in only a few cases has manifest scurvy been described $(35,48,49,52)$.

Depletion was demonstrated also by measuring ascorbic acid in whole blood of hospitalized patients (Table III) who had been treated by the Sippy régime.

TABLE III

Milligrams of ascorbic acid per 1000 cc. of whole blood

\begin{tabular}{|c|c|c|c|}
\hline Subject & Peptic ulcer & Subject & $\begin{array}{c}\text { Active } \\
\text { tuberculosis }\end{array}$ \\
\hline 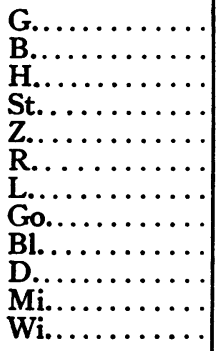 & $\begin{array}{l}2.3 \\
1.8 \\
1.8 \\
1.8 \\
1.8 \\
1.8 \\
2.7 \\
1.8 \\
3.0 \\
1.7 \\
3.1 \\
2.5\end{array}$ & 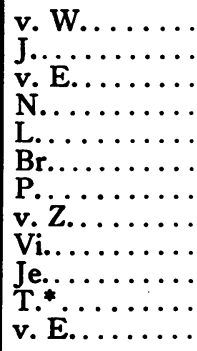 & $\begin{array}{l}2.7 \\
5.7 \\
6.7 \\
9.4 \\
3.0 \\
3.1 \\
3.3 \\
3.2 \\
5.7 \\
4.5 \\
1.8 \\
3.8\end{array}$ \\
\hline
\end{tabular}

* This patient had manifest symptoms of scurvy which were promptly influenced by ascorbic acid.

Table III also presents, for purposes of comparison, the ascorbic acid content in whole blood of a number of patients suffering from tuberculosis, whose requirements have been found to be greater than those of patients with peptic ulcer. The values observed in the blood of tuberculous patients are low in spite of large amounts of orange juice taken for a few weeks previous to the determination of the vitamin in blood. The low concentration of ascorbic acid in the blood 
of patients with peptic ulcer, on the average even lower than in cases of tuberculosis, is owing chiefly to the dietary treatment, which obviously provides an insufficient supply of the anti-ascorbic vitamin. In agreement with investigations in other countries $(53,54)$ pasteurized milk was found to contain between 0.4 and $1.0 \mathrm{mgm}$. per $100 \mathrm{cc}$. Since milk constitutes the main source of vitamin $C$ in the diet commonly prescribed, the daily intake during the first and second week of Sippy treatment, for instance, amounts to no more than 12 to $15 \mathrm{mgm}$. of ascorbic acid.

As has been stated before, about 2 mgm. or less of ascorbic acid per $1000 \mathrm{cc}$. of whole blood are observed in scurvy. Yet, in spite of levels lower than $2 \mathrm{mgm}$. per liter, none of these patients with peptic ulcers had any symptoms of scurvy, nor was capillary fragility increased. The freedom from scurvy may be due to the fact that they were hospitalized and had almost complete rest. Exercise has been found to increase requirements and to exhaust the stores of vitamin $C$ in rats (55). In this connection it is interesting to note that the only patient with scurvy-among the group with a blood level of less than $2 \mathrm{mgm}$.- had entered the hospital, after several days of activity, considerably too fatiguing for his condition.

Recently, requirements in two cases of peptic ulcer have been studied in a different way. After the concentration of ascorbic acid in his whole blood (56) had been measured, one patient who could not take food by mouth received $100 \mathrm{mgm}$. daily intravenously, another $60 \mathrm{mgm}$. per os plus about $12 \mathrm{mgm}$. daily with his diet. After 6 days, repeated analyses of blood showed that in the first patient $100 \mathrm{mgm}$. daily had not maintained the initial blood level, which had decreased from 9.3 mgm. per liter to $7.0 \mathrm{mgm}$. per liter. The second patient had only a slight decrease (14.5 to 13.5 mgm. per liter). His daily intake of about 75 mgm. probably just covered his requirements. Studied similarly, a patient with infectious mononucleosis with slight elevation of body temperature showed approximately normal requirements; the initial blood level of $14.0 \mathrm{mgm}$. per liter rose to 15.3 after receiving daily for 6 days $1.2 \mathrm{mgm}$. per $\mathrm{kgm}$. of body weight. This method does not permit an exact quantitative evaluation of daily requirements. Since it distinguishes between nor- mal and distinctly increased requirements in a fairly simple way, it is proposed as a clinical method.

The amount of ascorbic acid needed for saturation of the subject to be studied is estimated from the result of a preliminary analysis of whole blood (56). With a concentration of $8 \mathrm{mgm}$. per liter of whole blood about $1000 \mathrm{mgm}$. of ascorbic acid should be necessary, with $4 \mathrm{mgm}$. per liter, about $2000 \mathrm{mgm}$. (57). The amount presumably needed is supplied in single doses of 250 to $300 \mathrm{mgm}$. Then, after an interval of about 12 hours, the concentration of ascorbic acid in whole blood is determined. It should be about 10 to $12 \mathrm{mgm}$. This initial saturation, necessary because maximum requirements are used only by a subject nearly saturated, is followed by a daily supply of the estimated normal requirements, 0.8 mgm. per kgm. or even more when larger requirements are assumed, for one week. Another analysis of blood or the 8th day demonstrates whether the daily supply has been more than (rising concentration in blood), less than (decrease in blood), or just equal to the amount metabolized (no change in blood).

In this investigation, requirements in healthy subjects have been estimated from the effects of ascorbic acid administered per os. It has been claimed that smaller doses, injected intravenously (58) or subcutaneously (59) are sufficient. In a few diseased subjects, in whom the parenteral route has been chosen for certain reasons, the estimated requirements are about the same as when the vitamin is given by mouth.

\section{SUM MARY}

At least $0.8 \mathrm{mgm}$. of ascorbic acid per $\mathrm{kgm}$. of body weight is used daily by healthy subjects saturated with this vitamin. Smaller amounts maintain a lower concentration in the body stores. To protect against scurvy, $0.4 \mathrm{mgm}$. per $\mathrm{kgm}$. or even less per day appear to be sufficient.

Abnormally high requirements are observed in patients with active tuberculosis, but are not specific for this disease.

Requirements have been found to be increased to some extent in patients with peptic ulcer.

A comparatively simple method for rough estimation of daily requirements is proposed. 


\section{BIBLIOGRAPHY}

1. Giroud, A., Ratsimamanga, R., Baratte, A., and Sylva; F., Réactions des animaux carençables à des doses croissantes d'acide ascorbique. Compt. rend. Soc. de Biol., 1935, 120, 701.

2. Giroud, A., Leblond, C. P., and Ratsimamanga, R., The vitamin $C$ requirement of the guinea-pig. Yale J. Biol and Med., 1937, 9, 573.

3. Zilva, S. S., The ascorbic acid content of the intestine of the guinea pig. Biochem. J., 1935, 29, 100.

The effect of incomplete diets on the concentration of ascorbic acid in the organs of the rat. Ibid., 1936, 30, 857.

Vitamin $C$ requirements of the guinea pig. Ibid., 1936, 30, 1419.

4. Dann, M., and Cowgill, G. R., The vitamin C requirement of the guinea pig. J. Nutrition, 1935, 9, 507.

5. Fox, F. W., and Levy, L. F., Experiments confirming the antiscorbutic activity of dehydroascorbic acid and a study of its storage and that of ascorbic acid by the guinea pig at different levels of intake. Biochem. J., 1936, 30, 211.

6. Bessey, O. A., and King, C. G., The distribution of vitamin $C$ in plant and animal tissues and its determination. J. Biol. Chem., 1933, 103, 687.

7. van Eekelen, M., Over opname, verbruik en uitscheidung van vitamine $C$ door de mens. Thesis, 1936, Drukkerij Fa. Schotanus and Jens, Utrecht.

8. van Eekelen, M., On the amount of ascorbic acid in blood and urine. The daily human requirements for ascorbic acid. Biochem. J., 1936, 30, 2291.

9. Harris, L. L., Ray, S. N., and Ward, A., The excretion of vitamin $\mathrm{C}$ in human urine and its dependence on the dietary intake. Biochem. J., 1933, 27, 2011.

10. van Eekelen, M., Emmerie, A., Josephy, B., and Wolff, L. K., Investigations about vitamin C. Acta brev. Neerland., 1933, 3, 168.

11. Johnson, S. W., and Zilva, S. S., The urinary excretion of ascorbic and dehydroascorbic acids in man. Biochem. J., 1934, 28, 1393.

12. Göthlin, G. F., Methode zur Bestimmung der Festigkeit der Haut-capillaren und zu indirekter Beurteilung des individuellen C-vitamin standards. Klin. Wchnschr., 1932, 11, 1469.

13. Göthlin, G. F., Human daily requirements of dietary ascorbic acid.. Nature, 1934, 134, 569.

14. Göthlin, G. F., Frisell, E., and Rundqvist, N., Experimental determinations of the indispensable requirements of vitamin C (ascorbic acid) of the physically healthy adult. Acta Med. Scandinav., 1937, 92, 1.

15. Heinemann, M., Dietary influences on the amount of ascorbic acid and other reducing substances in urine. Acta brev. Neerland., 1936, 6, 67.

16. Heinemann, $M$., On the urinary excretion of thio- sulphate and ascorbic acid during different diets. Acta brev. Neerland., 1936, 6, 141.

17. Heinemann, $M .$, On the relation between diet and urinary output of thiosulphate (and ascorbic acid). II. Human requirements for vitamin C. Biochem. J., 1936, 30, 2299.

18. Heinemann, M., On human requirements for vitamin $C$ under different conditions. Acta brev. Neerland., 1936, 6, 144.

19. van Wersch, H. J., Determinations of the daily requirements for ascorbic acid of man. Acta brev. Neerland., 1936, 6, 86.

20. van Eekelen, M., Heinemann, M., and van Wersch, $H$. J., On the daily requirements for ascorbic acid. Acta brev. Neerland., 1936, 6, 107.

21. Szen-Györgi, A., Die medizinische Bedeutung des Vitamins C. Deutsche med. Wchnschr., 1934, 60, 556.

22. Widenbauer, F., Ascorbinsäurestudien an Säuglingen Klin. Wchnschr., 1936, 15, 815.

23. Neuweiler, W., Vitamin C-Stoffwechsel bei Neugeborenen. Ztschr. f. Vitaminforch., 1937, 6, 75.

24. O'Hara, P. H., and Hauck, H. M., Storage of vitamin $C$ by normal adults following a period of low intake. J. Nutrition, 1936, 12, 413.

25. Wachholder, $K$., Uber die Vitamin $\mathrm{C}$-Bilanz des Menschen. IV. Einschränkung des Bedarfes bei mangelhafter Zufuhr und deren ernahrungsphysiologische Bedeutung. Klin. Wchnschr., 1938, 17, 5.

26. Mosonyi, J., Skorbutische Stoffwechselstörung und Hyperthyreoidismus. Klin. Wchnschr., 1936, 15, 24.

27. Svirbely, J. L., The effect of desiccated thyroid, $\alpha$-dinitrophenol and cortical hormone extract on the vitamin C content of some organs of the guinea pig fed graded doses of ascorbic acid. J. Biol. Chem., 1935, 111, 147.

28. Kreitmair, H., Beiträge zur Pharmakologie der Ascorbinsäure (Vitamin C). Arch. f. exper. Path. u. Pharmakol., 1934, 176, 326.

29. Widenbauer, F., Der Vitamin C Haushalt des Menschen unter verschiedenen Verhältnissen. Klin. Wchnschr., 1937, 16, 600.

30. Mettier, S. R., Minot, G. R., and Townsend, W. C., Scurvy in adults. Especially the effect of food rich in vitamin C on blood formation. J. A. M. A., 1930, 95, 1089.

31. Schroeder, H., Die Ausscheidung der Ascorbinsäure im gesunden und kranken Organismus. Klin. Wchnschr., 1935, 14, 484.

32. Harris, L. J., Abbasy, M. A., Yudkin, J., and Kelly, S., Vitamins in human nutrition. Vitamin C reserves of subjects of the voluntary hospital class. Lancet, 1936, 1, 1488.

33. Bullowa, J. G. M., Rothstein, I. A., Ratish, H. D., and Harde, E., Cevitamic acid excretion in pneumonias and some other pathological conditions. Proc. Soc. Exper. Biol. and Med., 1936, 34, 1. 
34. Abbasy, M. A., Hill, N. G., and Harris, L. J., Vitamin $\mathrm{C}$ and juvenile rheumatism with some observations on the vitamin $\mathrm{C}$ reserves in surgical tuberculosis. Lancet, 1936, 2, 1413.

35. Wright, J. S., The present status of clinical use of cevitamic acid (ascorbic acid) (crystalline vitamin C). Am. J. M. Sc., 1936, 192, 719.

36. van Eekelen, M., and Heinemann, M., Critical remarks on the determination of urinary excretion of ascorbic acid. J. Clin. Invest., 1938, 17, 293.

37. Heinemann, M., Ascorbic acid requirements in human tuberculosis. Acta brev. Neerland., 1937, 7, 48.

38. Heinemann, M., Metabolism of ascorbic acid in human tuberculosis. Acta brev. Neerland., 1937, 7, 113.

39. Heise, F. H., and Martin, G. J., Ascorbic acid metabolism in tuberculosis. Proc. Soc. Exper. Biol. and Med., 1936, 34, 642.

40. Burckhardt, J. L., and Weiser, F., Ueber Vitamin C Ausscheidung bei tuberkulösen Kindern. Schweiz. med. Wchnschr., 1936, 66, 832.

41. Hasselbach, F., Vitamin $C$ und Lungertuberkulose. Ztschr. f. Tuberk., 1936, 75, 336.

42. Deggeller, O., Onderzoekingen over het gehalte aan vitamine-C van het bloed. Thesis, 1936, Drukkerij Fa. Schotanus and Jens, Utrecht.

43. Abbasy, M. A., Harris, L. J., Ray, S. N., and Marrack, J. R., Diagnosis of vitamin $C$ subnutrition by urine analysis. Quantitative data-experiments on control subjects. Lancet, 1935, 2, 1399.

44. Mouriquand, G., Rochaix, A., and Michel, P., Action réciproque du terrain scorbutique et de l'infection expérimentale par une tuberculose virulente. Compt. rend. Soc. de biol., 1924, 91, 205.

45. Heymann, B., Versuche an Meerschweinchen über die Beziehungen zwischen Skorbut und chronischer Tuberkulose. Klin. Wchnschr., 1926, 5, 59.

46. Delf, E. M., Studies in experimental scurvy-with special reference to the antiscorbutic properties of some South African foodstuffs. Publications of the South African Institute for Medical Research, 1921, 14, Johannesburg.
47. Tuberculosis Research Committee, Ibid., 1932, 30, Johannesburg.

48. Davidson, P. B., The development of deficiency disease during therapeutic diets. J. A. M. A., 1928, 90, 1014.

49. Archer, H. E., and Graham, G., The subscurvy state in relation to gastric and duodenal ulcer. Lancet, 1936, 2, 364.

50. Portnoy, B., and Wilkinson, J. F., Vitamin C deficiency in peptic ulceration and haematemesis. Brit. M. J., 1938, 1, 554.

51. Bourne, G., Vitamin $C$ deficiency in peptic ulceration estimated by the capillary resistance test. Brit. $M$. J., 1938, 1, 560.

52. Platt, R., Scurvy as the result of dietetic treatment. Lancet, 1936, 2, 366.

53. van Wijngaarden, J. C., Carotine, vitamin A en vitamine $C$ in koemelk. Thesis, 1935, Drukkerij P. den Boer, Utrecht.

54. Whitnah, C. H., and Riddell, W. H., Milk as a source of vitamin C. Science, 1936, 83, 162.

55. van Eekelen, M., and Kooy, R., The ascorbic acid content of suprarenal glands and livers from normal and fatigued rats. Acta brev. Neerland., 1933, 3, 169.

56. Emmerie, A., and van Eekelen, M., The chemical determination of vitamin $C$ with removal of interfering reducing and coloured substances. Biochem. J., 1934, 28, 1153.

57. van Eekelen, M., Emmerie, A., and Wolff, L. K., Ueber die Diagnostik der Hypovitaminosen $\mathrm{A}$ und $\mathrm{C}$ durch die Bestimmung dieser Vitamine im Blut. Ztschr. f. Vitaminforsch., 1937, 6, 151.

58. Schultzer, $P$., On the saturation of a scurvy patient with small doses of ascorbic acid. Consideration of the daily human requirements. Biochem. J., 1937, 31, 1934.

59. Hou, H. C., Comparison of oral and subcutaneous administration of protective doses of ascorbic acid (vitamin C). Proc. Soc. Exper. Biol. and Med., 1935, 32, 1391. 